\title{
Is Academic Economics Withering in Australia?
}

\author{
John Lodewijks and Tony Stokes ${ }^{1}$
}

\section{Abstract}

Departments of economics in Australia have not fared well recently. Many have been closed, merged or relocated, their staff made redundant while economics degrees and majors have been eliminated. This article tries to understand why academic economics appears to be withering in this country, or at least increasingly concentrated in Group of Eight (Go8) universities, and what if anything can still be done to preserve what is left.

\section{Introduction}

The recent news reports that the La Trobe School of Economics is being forced to reduce its established positions from 28 to just 10 is the latest in a series of cutbacks being imposed on academic economists in Australia. At La Trobe the proposed cuts include three professorial positions and three Associate Professors. Its stand-alone economics degree will no longer be offered from 2015. The developments at La Trobe are a carbon copy of what happened at the University of Western Sydney starting in late 2012. Four Economics professors were made redundant, along with seven other staff, and their B.Ec. no longer admitted students from 2013. ${ }^{2}$ These have been high-profile media events. Less well-known is the disappearance of Victoria University's Department of Applied Economics, with staff scattered across Finance and International Business. A similar story of economics being subsumed within Business unfolded at the University of Newcastle, the University of New England, the University

\footnotetext{
1 University of New South Wales, j.lodewijks@unsw.edu.au; Australian Catholic University, Tony.Stokes@ acu.edu.au. Very helpful comments were received from Max Corden, Tony Endres, Noel Gaston, Margaret Giles, Raja Junankar, Michael McLure, Gregory Moore, Paul Oslington, Sriram Shankar, Tim Thornton, the Editor and two anonymous referees.

2 A referee notes that while the B Ec has been abolished at UWS, there is still a Bachelor of Business and Commerce (Economics). This major was not in the original restructuring proposal and came as a concession afterwards and has a minimal number of economics units. Moreover, even the first-year core economics unit was set for abolition until someone made the Dean aware that it was required for accounting accreditation purposes.
} 
of Tasmania and James Cook University. Griffith University has reduced the number of offerings in Economics and there are reported upper-level enrolment concerns at ANU.

At Edith Cowan University the economics major in the Bachelor of Business degree has been discontinued; there are no new enrolments in the major from 2014 and existing economics major students are taking second and third-year economics units in teach-out mode. There is even a move to dispense with the first-year economics unit in the business degree. In 2013 ECU had eight economics teaching staff. Four of these now remain. Of these, three are teaching finance and quantitative methods. Only one staff member remains to teach economics. Curtin has also faced serious staff redundancies. Some of the staff made redundant by Curtin University have been picked up as casuals to fill the ECU gaps in teaching economics at the undergraduate and postgraduate levels in 2014. The B.Ec. is also no longer offered at UWA.

Economics at the University of Sydney has been ejected from the Business faculty and transferred to Arts. At the Australian Catholic University the same occurred. The Faculty of Business declined to have the economics major in the Faculty and subsequently retrenched the only professor of economics in the university. Even boutique economic programs that deliberately seek to remain small for pedagogical reasons, such as on the Fremantle campus of Notre Dame Australia, struggle to recruit a sufficient number of students. Their required targets are only just achieved by enrolling visiting Notre Dame Indiana students and finance students doing economics units as electives.

Across the Tasman Sea the situation is similar. Agnew (2014) reports a 31 per cent decline in economics enrolment in New Zealand secondary schools between 2003 and 2012, and a 20 per cent decline in the number of students enrolled in an economics bachelor degree in a New Zealand university from 2008 to 2012. In 2014 three economists were made redundant at the University of Canterbury. Other universities, such as the University of Auckland, are scrambling to attract more students to ward off impending attacks.

We badly need a comprehensive stock take of what is happening to academic economics in this country and New Zealand. ${ }^{3}$ Questions for each university might include: How many academic economists are in your department/school/ faculty? Have these numbers fallen in the last five years? Do you have a B.Ec.? What has been happening to your economics enrolments over the last five

3 The often-cited paper by Lewis and Norris (1997) on economics enrolments was commissioned by the ESA. After 17 years, it is now time for the ESA to commission a follow-up report. We also need to have a survey of the large consulting firms (e.g. KPMG, Deloitte) and government departments (e.g. DSS, Health, Treasury) about the crucial role that economists play in these organisations and what they would like the new recruits to know/understand about economics. 
years? Do you have an Honours program? How many economics subjects/units/ courses (whatever you call them) do you offer? Have these numbers fallen in the last five years? Do you have any comments on the overall health of (or likely threats to) your economics programs? Such a survey should be undertaken with a sense of urgency by the central office of the Economic Society of Australia (ESA). To thoroughly investigate the matter, the ESA needs to differentiate what is happening in Go8 and non-Go8 universities and it needs to weight the overall results by each university's FTE enrolments and staff size. Using simple averages would give the same weight to a large department, such as Melbourne, as it does to a far smaller economics program with a handful of staff. The examples already presented indicate that all is certainly not well and we may need to act before the full survey results are available. One economist has told us that 'economics is about to die in this country'. Another wrote: 'I just returned from the ESAM/ ACE in Hobart. I and just about everybody else there (including visitors from overseas at the conference dinner Table I was sitting at) signed a letter being circulated on behalf of the La Trobe people. It's a disgrace. ${ }^{4}$ We cannot afford to wait.

While the dramatic closures reported above have happened only very recently, the declining status of academic economics has been more long term. We need to understand why academic economics appears to be withering in this country and the likely consequences unless this decline is reversed.

\section{Decline and fall}

Historically, the 1960s and 1970s are described as the 'glory days' for the study of economics at tertiary institutions. For more than two decades the popularity of the economics degree in Australian universities has been in decline. Just over a decade ago Maxwell (2003) wrote on 'The Rise and Fall (?) of Economics in Australian Universities'. He suggested that the early to mid-1980s may have been the highpoint of economics in universities. Between 1995 and 2000 six separate economics departments disappeared and in net terms between 60 and 70 economists left the university system. The decline mainly occurred in middle-size and small departments of economics. Over the period 1991-2000 university economics enrolment as a proportion of total EFTSUs fell from 5 per cent to 3.6 per cent and as a ratio of total business enrolment from 0.251 to 0.139 . However, Maxwell was optimistic that this might be turned around and hence the question mark in his title. He is to be commended for his positive suggestions on how to improve the fortunes of economics via better marketing efforts, restoring our public image, changing the nature and structure of our

4 The letter was signed by over 100 academics and members of the profession from around Australia. 
teaching programs to make the discipline more relevant to students, improving our teaching quality and applying new information technology. Yet recent events suggest that his hopes have been dashed.

Another excellent source of data on declining economics enrolments is Alauddin and Valadkhani (2003). The first sentence of their article reads: 'There is a general consensus among economists that the number of enrolments in economics is in a state of steady decline globally over a period of nearly two decades. ${ }^{5}$ Their data clearly indicate the steady marginalisation of economics as a discipline and the ascendancy of business and related disciplines. The reasons for this decline in Australia have been widely debated. A survey of 35 heads of economics disciplines in Australian universities, undertaken in April 1996, described the causes of falling enrolments as a perception of business studies being more career-focused than economics; that economics was seen as too rigorous or abstract; and that students were less well-prepared in mathematics (Lewis and Norris 1997). Educators suggest we need to respond to changing market conditions by adapting the 'product', the method of delivery, or the appeal of the economics degree to ensure economics is seen as intrinsically interesting and relevant to careers (Round and Shanahan 2010).

The decline appears clearly related to the decline in the study of economics in the high schools. In 1989, 21,211 candidates undertook the Economics examination in NSW across the three courses in the subject (39 per cent of the total candidature). Economics was the third-largest individual subject, after English and Mathematics. By 2013, out of the 75,168 students enrolled in the NSW Higher School Certificate, only 5,335 studied Economics (63 per cent male, 37 per cent female). Business Studies (a course not available in 1989) had 16,020 candidates (51 per cent male, 49 per cent female) and was ranked the fourthmost popular subject by course enrolment. John Conroy, writing in the Business Spectator of the 1 June 2012, noted that:

5 In the period 1990-2006 there was a general decline in the numbers of students majoring in economics at universities, not only in Australia (Lewis and Norris 1997; Millmow 2006) but throughout the world (Becker 2004; Siegfried 2000, 2006). In some nations this decline has been reversed since the time of the global financial crisis (GFC), as it is known in Australia, or The Great Recession, as referred to in the US. Siegfried (2012) reports that undergraduate degrees in economics awarded by US colleges and universities rose between 2008 and 2011. In that period, economics degrees awarded by public colleges and universities increased by 11 per cent (compared to a 4 per cent increase among private institutions). Siegfried (2012) considers that one factor that could have led to this turnaround was the 'Freakonomics effect' (Levitt and Dubner 2005). Siegfried considers that the increased interest in economics as a result of Levitt and Dubner's best-selling book led to an increase in the numbers pursuing undergraduate economics degrees.

In the UK there was a similar turnaround in economics undergraduate enrolments in 2008 and 2009, increasing 26.7 per cent in the period. This spurt could be attributed to the GFC and the interest that created in understanding economics. This hypothesis is supported by the fact that economics enrolments fell in the UK in 2010, as the novelty of the GFC wore off. One could question then why this growth did not occur in Australia. Australia was not as severely affected by the GFC as the UK and the 'Freakonomics effect' was not as widely read as in the US. Perhaps a solution to the problem of declining economics numbers in Australia goes back to the issue of relevance and promotion in a contemporary environment. 
While Australians constantly put 'the economy' at the top of government's priorities, the trend in education is that fewer and fewer students are taking economics in favour of more narrowly focused business studies. Twenty years ago business studies and variations on it, such as business management, were introduced into Australian Year 11 and 12 syllabuses. In the two decades leading up to business being introduced in New South Wales in 1991, 35 to 40 per cent of students studied economics in their final year of high school. Today that number has been eroded to about 8 per cent. Students slowly migrated across to business courses, overtaking economics enrolments in the mid-1990s and completing the transition in the mid-2000s - the figures have stayed roughly the same since, with about 25 per cent of students taking business studies and 8 per cent economics.

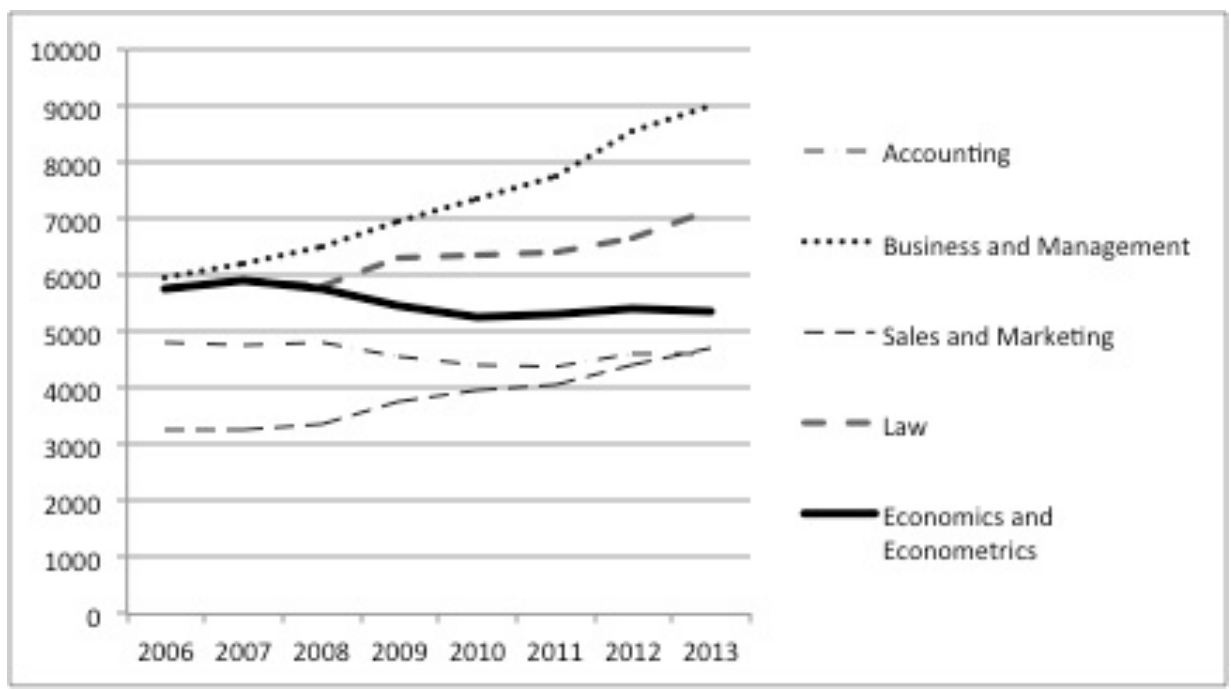

Figure 1: Commencing domestic student numbers across various degrees in Australia, 2006-2013

Source: Australian Government Department of Education (various years), Selected Higher Education Statistics.

Figure 1 indicates the decline of economics (including econometrics) enrolments in Australian undergraduate university courses, despite the increase in the overall numbers of commencing domestic bachelor degree students in recent years with the uncapping of university places. In the period 2006-13, there was an overall growth of 39 per cent in commencing domestic student numbers across all bachelor courses. Business and management numbers rose 52 per cent, marketing and sales 44 per cent and law 25 per cent. At the same time the numbers of commencing economics students declined 7 per cent from 5,781 students to 
5,384 students. The fall in the number of students commencing accountancy by 4 per cent during the period could also suggest that commencing students are turning away from the more rigorous mathematically orientated courses to more descriptive and perceived easier options.

In recent years the uncapping of university places has led to a decline in entry standards in a number of universities across Australia. Table 1 and Table 2 indicate widespread declining university admission standards in the lower Australian Tertiary Admission Rank (ATAR) level universities. This has been even more noticeable in the more competitive markets in Sydney and Melbourne, compared to the areas of fewer university choices. It should be noted that while it appears that the higher ATAR (usually Go8) universities may have increased their entry requirements in some cases, it is important to remember that most universities now offer up to 10 bonus points that they will allocate to students. This would suggest an additional eroding of standards that is not reflected in the published ATAR scores. ${ }^{6}$ It is no coincidence that as universities have aggressively expanded enrolments, with the extra students less-prepared than earlier cohorts, these students have found that the intellectual demands and quantitative requirements that economics poses are a major deterrent and they are far more comfortable enrolling in other business programs. Maxwell (2003: 79) describes this nicely as a 'hardening of the discipline' coming up against the 'softening in preparation of students' combined with the rise of more fashionable fields of study which students perceive as being 'more suited to their vocational needs'. ${ }^{7}$

Table 1: Australian Tertiary Admission Rank (ATAR) 2007 and 2014 ${ }^{a}$

\begin{tabular}{lcrrr}
\hline University & $\begin{array}{c}2007 \\
\text { Arts }\end{array}$ & $\begin{array}{c}\text { 2007 Business/ } \\
\text { Commerce }\end{array}$ & $\begin{array}{c}\text { 2014 } \\
\text { Arts }\end{array}$ & $\begin{array}{c}\text { 2014 Business/ } \\
\text { Commerce }\end{array}$ \\
\hline Average for Go8 & 82.43 & 88.39 & 80.01 & 89.09 \\
Average for non-Go8 & 70.78 & 72.87 & 64.04 & 65.09 \\
\hline
\end{tabular}

a For 2007 the entry scores have been adjusted to an equivalent ATAR, using the Universities Admission Centre conversion table.

Source: UAC $(2007,2014)$, individual university and other sources.

\footnotetext{
6 What is also important for the quality of intake is the distribution of students above the cut-off point. If the last student to enter has a low ATAR score while everyone else has a high one, there may be no change in the average quality at entry. This of course assumes that ATAR adequately measures the quality of students. However, universities do not divulge mean or median entry scores as there appears to be a lot of the gaming of the system going on as well as direct admissions outside of the formal entry process. Some low ATAR universities have median entry scores only 3-5 marks above the official cut-off as there are students admitted below the cut-offs, including those allocated bonus points for a wide variety of reasons often relating to socioeconomic disadvantage or coming from regional areas or from a close locality and so on.

7 Evidence that a degree in Economics is 'vocational' is provided by the estimated rate of return to an economics degree reported in Daly \& Lewis (2010). An economics degree is well-regarded in the labour market and this may become increasingly so as employers turn away from more general business degrees.
} 
Table 2: Australian Tertiary Admissions Rank (ATAR) 2007 and 2014a

\begin{tabular}{|c|c|c|c|c|}
\hline University & $\begin{array}{l}2007 \\
\text { Arts }\end{array}$ & $\begin{array}{c}2007 \text { Business/ } \\
\text { Commerce }\end{array}$ & $\begin{array}{l}2014 \\
\text { Arts }\end{array}$ & $\begin{array}{c}2014 \text { Business/ } \\
\text { Commerce }\end{array}$ \\
\hline University of Sydney & 84.4 & 95.35 & 81.1 & 95 \\
\hline University of New South Wales & 81.65 & 95.5 & 78 & 96.3 \\
\hline Monash University & 87 & 91 & 80.1 & 90.3 \\
\hline Australian National University & 77.1 & 77.1 & 80 & 82 \\
\hline University of Western Australia & 82 & 83 & 80 & 80 \\
\hline University of Technology, Sydney & 84 & 91 & 78 & 90 \\
\hline Macquarie University & 81.45 & 84.55 & 75 & 81 \\
\hline University of New England & 72 & 72 & 72.6 & 72.6 \\
\hline University of Wollongong & 79.85 & 81.65 & 70 & 72 \\
\hline Curtin University & 72 & 77 & 70 & 70 \\
\hline Murdoch University & 69.8 & 67.8 & 70 & 70 \\
\hline University of Western Sydney & 72.6 & 73.55 & 70 & 65 \\
\hline Southern Cross University & 67.5 & 67.5 & 68 & 65 \\
\hline Charles Sturt University & 72 & 72 & 65 & 65 \\
\hline University of Canberra & 68.9 & 67.95 & 66 & 66 \\
\hline Griffith University & 65.9 & 68.5 & 63 & 68.5 \\
\hline University of Newcastle & 67.35 & 67.35 & 60 & 60.3 \\
\hline $\begin{array}{l}\text { Swinburne University of } \\
\text { Technology }\end{array}$ & 78 & 78.8 & 60 & 60 \\
\hline Australian Catholic University & 68.05 & 72.7 & 58.9 & 58.7 \\
\hline Deakin University & 67 & 63 & 51.4 & 61.9 \\
\hline La Trobe University & 70.5 & 74 & 50.1 & 55 \\
\hline Edith Cowan University & 58 & 62.5 & 55 & 55 \\
\hline Victoria University & 63 & 64 & 50.2 & 45.3 \\
\hline
\end{tabular}

a. For 2007 the entry scores have been adjusted to an equivalent ATAR, using the Universities Admission Centre conversion table.

\section{Some self-inflicted wounds}

It can be conjectured that the reported failure of economists to predict the global financial crisis might be one reason for the declining enrolment. Conversely, it may be the case that we should have expected a pick-up in student numbers, as apparently occurred in some other countries, as a result of the GFC. Millmow and Tuck (2011) indicate that the latter did not happen. Perhaps of greater importance is the negative way that economics is often portrayed in the media. 
Many commentators have heaped scorn on economists and economics. This is extensively discussed in Coleman and Hagger (2001) and Coleman (2004). Very rarely do we see stories of the positive contribution that economics has made to public policy debate and overall economic prosperity in this country. In most of the major policy debates, economists have made fundamental contributions ranging from the Industries Assistance Commission on tariff reform through to Ross Garnaut on climate change. It is the positive stories that are not being communicated to the public. The profession needs a whole new image as a vital contributor to business and policy debate. Perhaps there is a case for leaving internal dissent 'in-house' to be articulated in academic conferences, seminars and journals without airing our dirty laundry in public. Or if this is seen as too restrictive, presenting alternative approaches in the media in a positive light that illustrates alternative solutions or policy proposals without denigrating those of opposed views. It is the credibility of the profession that is at stake here.

Another aspect of this internal bickering relates to the two rounds of the Excellence in Research for Australia (ERA) audit organised by the Australian Research Council. Serious concerns have been raised about the adequacy of the ERA audits to accurately and fairly judge the full breadth of economic research (Bloch 2012). The ERAl audit showed that two-thirds of universities that were assessed in applied economics, as well as the overall economics discipline, were rated as 'below world standard'. The implication of ERAl was that Australia generally is very poor in economics research by world standards. At the twodigit level (14 Economics) 40 per cent of assessable economics units were given the lowest possible rating of 1 representing 'well below world standard'. By comparison, in the humanities and creative arts, less than 10 per cent of institutions received a 1 ranking across all fields, including law. The overall average for economics was 2.4. We only achieved world standard (just) in economic theory 3.1 and econometrics 3.3; we scored 2.1 in applied economics. Note that applied economists account for 66 per cent of all Australian economists, 80 per cent of the research grants and 76 per cent of publications. Are we really that bad?

Much of these research ratings depended on journal rankings. Only 28 per cent of applied economics journals ranked $\mathrm{A}$ or $\mathrm{A}^{*}$, whereas in economic theory it is 42 per cent and econometrics 57 per cent. In applied economics only four out of 35 universities got a 4 or a 5 . The results for ERA2 for economics show modest improvement. The overall economics average was 3.2 (now just above world average), with 62 per cent of institutions scoring 3 or above. In applied economics 53 per cent of institutions scored 3 or above, there were no 1s, and 47 per cent scored a 2, with an overall average of 2.87 . But the mode was 2 ('below world standard') - with 14 institutions achieving this score. 
An increasing proportion of a university's research funding is based on ERA outcomes and hence there is reduced funding within universities for low-ranked research codes. As such, the perceived 'value' of academic economists in many universities is very low and if they perform 'below world standard' or even just at that standard, why persist with them when a better return on research resources can be obtained in disciplines with far higher ERA rankings? But who generates these rankings? It is the economists on the various committees and the assessors. Why are we shooting ourselves in the foot? Other disciplines seem to be coordinating their efforts to advance the interests of their profession. We seem intent on dragging ourselves down. The end result is that these ERA exercises rank the quality of economics research far lower than an objective assessment of the data (see Davidson 2013).

A similar story played out most recently in the latest Australian Business Deans Council (ABDC) journal ratings. While other business disciplines were busy getting more of the journals they publish in ranked, and raising the rankings of as many journals as they could, particularly at the $\mathrm{A}^{*}$ and A level, in economics we were doing the opposite. In particular, a submission from UTS recommended taking large numbers of journals that we might occasionally publish in out of the economics classification altogether and downgrading a whole lot of other established journals, some from an A ranking to a $\mathrm{C}$. The latest ABDC journal ranking list for all the FOR codes has 27.7 per cent of all journals ranked $A$ or $\mathrm{A}^{*}$. In Applied Economics it is only 23 per cent. In Marketing and Tourism it is 25 per cent, Business and Management (with 821 journals compared to the 500 in Applied Economics) it is 30.2 per cent, Management Other scores 39.4 per cent, while Commercial and Contract Law achieves an overwhelming 44.2 per cent. Consistent with Bloch's (2012) argument of a clear bias in our rankings towards economic theory and econometrics, the proportion of ABDC $\mathrm{A}$ and $\mathrm{A}^{*}$ journals in Economic Theory is 43.3 per cent and in Econometrics 42.4 per cent but the vast bulk of our research output is in Applied Economics, which languishes twenty percentage points lower in the ratings.

At least in the latest ABDC ranking process the Economic Society argued that the Economic Record should be an $\mathrm{A}^{*}$ rather than an A-rated journal but that support had apparently no effect on the final outcome. We are reminded of a heads of department meeting at ACE a few years ago when one head totally rubbished the Economic Record and said he would not even consider sending an article there. What sort of support is that for our leading journal? Economists have not played the game of self-promotion for the profession as a whole, rather than for their personal advantage. For a profession that prides itself on understanding the role of incentives and strategy, the outcomes for economics journal rankings is extraordinary. Given that promotion and research funding is increasingly fixated on top-ranked journal publication, why are we again 
causing self-inflicted harm by undermining our colleagues. Are we a selfish lot? Why is there no collective action to advance our interests rather than having mavericks that undermine it?

A further aspect of self-inflicted agonies is a point that Tony Endres made to us that economics has been 'fractured, sliced and diced-up by other disciplines and shared-around in business schools'. The often narrow content of economics instruction blocks students from wider backgrounds doing double-majors with economics in areas such as psychology, political science, sociology, anthropology and geography. Conversely, economics has been 'colonised' by cognate disciplines in business schools. For example, new institutional approaches to the firm (Coase, Williamson), business and economic history, including institutional aspects of economic organisation, and theoretical aspects of entrepreneurship are now being researched and taught in management studies. Institutional and behavioural aspects of international finance are being taught in courses in departments of finance, while development economics is widely taught as 'Development Studies' in arts faculties. The term 'colonisation' is perhaps not the right one in all cases since it implies an unwilling relinquishment. It may instead be 'self-inflicted' as these areas are often regarded as 'peripheral' to our disciplinary focus. Such a view adds to our current problems.

If current trends persist, will there be anyone left to teach economics in the schools? In 2012 there was a meeting between the executive of Business Educators Australasia (BEA) $)^{8}$ and Ed Wilson and Tony Stokes of the Economic Society of Australia (NSW branch). The topic of discussion was what could be done to increase the numbers studying economics in Australian schools and universities. The BEA raised serious concerns regarding the low numbers of economics graduates going into teaching. While some states, such as NSW, were coping reasonably well, in other states, such as Queensland, the situation was dire. Schools had little choice but employ teachers with one unit of economics (business economics) or no economics to teach economics to years 11 and 12 students. The key plea from the BEA was for universities to create positive learning environments in economics, with high-quality teaching to motivate students to consider teaching careers. Alas, it was explained to the BEA, most university staff did not see quality teaching and learning outcomes as the source of reward or promotion but that universities were obsessed with high-quality research performance and the funds that could be gained from that.

Another key issue associated with having school teachers with limited or no qualifications in economics is that they tend to favour the subjects in which they are qualified and may turn students away from studying economics. In

8 Business Educators Australasia is the national association for school teachers of economics and business education. 
addition, schools may not offer economics as a subject if they cannot get an economics teacher. All of this worsens the situation in schools and, subsequently, universities.

\section{Perverse incentives}

There seems little dispute that there has been considerable Americanisation of Australian economics. The incentive structures are such that in order to achieve high-level research outcomes, academics need to publish in the top journals and these are predominantly American and require advanced modelling skills and econometric techniques. Applied Australian research is usually not the sort of content that is readily acceptable in these journals. This has several consequences. First, academics have to be highly skilled in theory and/ or econometrics and certainly at the undergraduate level they find that most students do not share their passion for this sort of work. This being the case, many of the top academics avoid lower-level teaching and focus on honours and Ph.D.-level courses. Given the incentive structure, the clear signal is to minimise one's teaching load in general to concentrate on research. Secondly, there is less interest in specifically local policy concerns incorporating the institutional characteristics of the Australian economy. ${ }^{9}$ Yet it was that sort of 'small economy' modelling that generated the international renown of Kemp, Swan, Harcourt, Corden, Gregory and others in international trade and labour economics. Similar examples can be drawn from agricultural economics. Our international prominence, with notable exceptions, has undoubtedly fallen. ${ }^{10}$

The point, however, is that we have slanted our teaching to mimic our research focus and not to cater to the composition of the student body we now face. At least at the lower levels of undergraduate teaching we need to impart, and to let students apply, the basic skills and techniques that make economics so valuable as a policy science. At a macroeconomic level, we need policy simulations so that students can select different parameter values and themselves see what it does to macroeconomic targets and how shocks affect aggregate performance. They need to be able to replicate the behaviour of the Reserve Bank of Australia (RBA) and appreciate the complexities of setting a cash rate in a global environment. Combined with this they need to be able to use basic quantitative techniques

9 Coleman (2013: 24-6) sees the situation this way: 'What Australia has absorbed in full measure is an "International style"; a kind of economics that has no nationality, and looks the same wherever it is found across the world. ... the only rational choice for any talent is to participate in some global research project addressing "big", universal and enduring questions ... In Australia today there is economics aplenty. But there is no Australia in economics any longer. Australian economics is at an end.'

10 Paul Oslington notes that while the focus here is on undergraduate teaching programs, other aspects include the disappearance of quality Ph.D. students to the US, and the declining influence of economists on public policy which flows from the 'perverse' incentives mentioned. 
without always having to derive the theory behind them from first principles. At a microeconomic level it is the repeated application of a small set of basic principles relating to opportunity cost, decisions at the margin, price-quantity interactions, externalities, competitive dynamics and, particularly, cost-benefit analysis that is needed. Students should work through repeated examples of investment proposals that need to be evaluated, present values and rates of return calculated. It is these skills that set us apart and raise the employability of our average graduates. The other bells and whistles can be covered at higher levels and particularly during the Honours year. We should not be selfreplicating Ph.D. trained academics when we teach the bulk of students we encounter. I think we need to face the fact that a vast majority of our students are not going to do a Ph.D. but only complete an undergraduate degree with often just minimal exposure to economics. Stephen King (2012) put it as follows:

Economics is a public policy discipline. It is useful in many areas but its main role is to provide a set of tools to think about markets. Students need to understand what tools to use where and when. So they need the assumptions. But they also need context. Students need examples of where models work (and where they don't and why). They need economics linked to current policy debates and to economic history. The discipline has largely abandoned its own history in teaching - which is completely mad. If we teach economics in a vacuum, then that is all we will leave with students - an economics vacuum.

In sum, we should focus more on the practical application of economic models, develop more fully basic data-analysis skills and communicate our ideas better to non-economists and to those students not pursuing economics majors. We also need to be open to different ways to hold the attention of the modern student. For example, at UNSW in first-year microeconomics they use 'Playconomics', an online game that sets up economic environments and allows students to interact with other agents, make economic decisions and analyse the outcomes. Students can play the game in their own time, on their own devices and can progress at their own speed. ${ }^{11}$

This is not to say that we should not hire staff trained at the best US universities. To do otherwise we put us at risk us of becoming an academic backwater. It does mean that we have to more consciously differentiate what and how we research with what and how we teach. While there are undoubted economies of scale and scope to closely mesh the two this should be left for higher-level units. There may even be a case, as the University of Canterbury has demonstrated,

11 Another positive sign is the development of the excellent student economics site - http:// economicstudents.com/ - created by the Economics Student Society of Australia. This Society was founded in February 2012 at the University of Melbourne 'by a group of friends who love economics'. It is now the largest student economics society of its kind in Australia, spanning both Melbourne and Monash universities. 
that there are benefits to bringing in enthusiastic teaching-focused staff to teach the first years, and perhaps some of the second-year units, in ways that students find appealing and that induces them to go on with an economics major. Moreover, in our research effort we need a balance between hitting the top journals ${ }^{12}$ and preparing graduates for public policy and contributing to Australian policy discussion. Staff incentive structures need to encourage such research endeavours.

\section{Why we should bother}

The sceptics and naysayers will no doubt object. We have heard it said on numerous occasions that we shouldn't teach economics in the high schools but wait until they get to university; that what is taught at the high-school level is inappropriate and too current-affairs focused. It has also been said that economics is taught badly at the weaker universities and it is best concentrated in the Group of Eight, where it can be taught rigorously to high-achieving students. ${ }^{13}$ These perspectives see nothing wrong with the dramatic decline in economics enrolments at both the school and university level. After all, it is a market phenomenon and we are selling the wrong type of product or at best it is a product that cannot be appreciated by misinformed consumers.

Others respond that the suggestion that the economics discipline in Australia is in a perilous situation is an overstatement of the extent of any deterioration. While Curtin has faced serious staff redundancies, the Curtin Business School has also recently received in the vicinity of $\$ 10$ million to establish the Bankwest Curtin Economics Centre, which is employing high-profile economists. Similarly, while economics at both the University of Sydney and the Australian Catholic University has been ejected from the Business faculty and transferred to Arts, is the latter may well prove to be a more hospitable environment. As economics is a social science, is not placing economics in arts quite a sensible thing to do?

Additionally, some of the change in the numbers taking economics degrees might just reflect changes in the naming of degrees. For example, instead of majoring

\footnotetext{
12 A recent study (Card and DellaVigna 2013) found that hitting these journals was increasingly difficult. They found that annual submissions to the top five journals nearly doubled from 1990 to 2012 while the total number of articles published in these journals actually declined from 400 per year in the late 1970s to 300 per year most recently. As a result, the acceptance rate has fallen from 15 per cent to 6 per cent, with potential adverse implications for the career progression of young scholars.

13 One reader of our paper commented: 'I am also afraid to say that [this] is true. The fact of the matter is that many economists in the marginal universities just do not know the different economic models or the mathematics. (None of my sessionals, for example, can teach intermediate mathematics and none use mathematical formalism in their classes).... It also does not mean that economics is necessarily taught well at the senior universities. It is just taught badly in a different way (mainly because they are so specialised that they cannot really teach outside their area of expertise and in an intuitive fashion).'
} 
in marketing as part of an economics degree, students now have the option to do a marketing degree. Or it may reflect broader university policy changes that may not impact on economics enrolment. To take an example, while the B.Ec. is no longer offered at UWA this has everything to do with UWA reducing the number of degrees offered and nothing to do with a reduced demand or supply of economics at UWA. Economics is still offered in the B.Com, as either a 'double major in economics' (which basically offers the same range of economics subjects as the old B.Ec) or a 'single major'. The number of economists at UWA has held pretty firm. Overall, more students are studying economics under the B.Com than the old B.Ec, but fewer are studying the full range of subjects. They have far more 'single major' economics students (who study eight economics units, including two micro and two macro) in the B.Com than 'double major' economics students (who study 15 units), but the spread of students across the various classes is holding up.

While the situation at UWA is reassuring, some of the other WA universities are alleging that the predatory practices that UWA employs to maintain enrolments has come at a cost to them. The UWA economics entry mark is 80 , far lower than average Go8 business/commerce cut-offs reported in Table 1. Indeed, with the various discounts available for disadvantaged high schools the cut-off may well be lower. This squeezes out the intake of reasonable economics students at the other universities and they are forced to lower their entry scores even more and attract far less well-prepared students.

Such actions, if demonstrated, are dangerous in that they lead to a zero-sum game for the profession as a whole, although they may benefit particular institutions. Economics training should be supported wherever it is delivered. John Quiggin (2012) said it best:

Economics is the foundation discipline for studies in business, finance, accounting and related fields. A tertiary institution that offers a business degree without economics is not a real university, any more than one that that fails to offer Arts or Science degrees. One of the most distressing results of Australian higher education policy over the past twenty years is the re-emergence of a sharp division in which 'sandstone' universities, catering largely to the private-school educated children of the upper-middle classes offer degrees comparable to those of high-quality private and public universities in the US and elsewhere, while regional and working-class students are streamed into institutions offering 'vocational' degrees. In many cases, including that of business degrees without a disciplinary foundation, these are not even particularly valuable credentials in the employment market ... Offering them supposedly vocational degrees with no real disciplinary foundation is a cruel fraud and a dereliction of educational duty. 
A cornerstone of a democratic society is economic literacy. Some of the toughest issues confronting society are rapid structural, technological and demographic change, macroeconomic turbulence, global warming, and growing income inequality; therefore some of our biggest challenges will be to design tax, health, welfare and education systems, along with competition and industrial laws that balance equity and efficiency, and robust macroeconomic policies for an integrated world economy. The performance of our economy impacts on the availability of jobs, mortgage interest rates, the value of the Australian dollar, the prices we pay in the supermarket and our overall standard of living. In short, economic performance affects everyone. We desperately need economically literate citizens who understand these public policy challenges. The more students who are exposed to economics the better. Unfortunately, fewer students are taking economics in high school and in response to the fall in economics enrolments at universities there are fewer economics units being offered and the formerly mandatory two units of economics in first year for all business students is being replaced with a single unit combining both micro and macro but neither in the depth required.

\section{Are we self-obsessed?}

While our main concern here is the economics discipline and its perilous situation, we need to acknowledge that what is currently happening is in a context of extensive changes in the higher education sector. The loss of 18 economics positions at La Trobe is part of a planned redundancy of 69 academic positions at its business, economics and law faculty and an overall widespread cost-cutting restructure of the university in which 350 jobs are expected to be shed. At UWS the 11 economics redundancies were in the context of 30 redundancies in the School of Business overall and more in other parts of the university. The same general cuts happened at Bond, Curtin and many others. Economics was a casualty but there were many more. These are turbulent times and the notion of tenure has largely disappeared as the Federal government's financial contribution has declined in relative terms and the struggle for survival in competitive student markets intensifies.

The current reality is that corporate managerialism has replaced collegial systems of administration. Universities are in a state of flux and they are strategically reweighting their priorities. This has an adverse impact on economics but on many other disciplines as well. There is less tolerance for self-directed research that is unrelated to external funding and not supported by citation and impact ratings. We appear to be seeing a substantial increase in the concentration of economics education in the Go8 universities. But even within the Go8 there is increased concentration. Four universities - Melbourne, the University of 
Queensland, UNSW and ANU - appear to be setting themselves apart. For the non-Go8, the future may involve a return to the pre-Dawkins era. The current vast disparities in teaching loads among Go8 and non-Go8 departments - with the latter sometimes teaching four or more times the contact hours per semester than the former - is a clear case in point.

Economists have not been quiet in the face of the new corporate managerial culture. Harry Clarke (1998: 55), in a strident polemic entitled 'Dumbing-down in Australian universities', writes that:

Courses are established to be attractive to students (now described as 'clients' or 'customers' of the university) by having apparent vocational appeal with unchallenging subject matter and assessment ... Academically weak students, facing the option of choosing between challenging, analytical courses or descriptive, narrow courses with little intellectual challenge, tend to go for the latter if that is where they see apparent vocational opportunity.

Murray and Dollery (2006) comment that administrators have sometimes acted despotically, without regard to logic and fairness, and the costs incurred in organisational restructures were often far in excess of any derived benefit. The personal costs of such outspoken dissent can often be high, as Tom Valentine found out at both Macquarie University and UWS. While these individual expressions of dissent (or whistle-blowers in the case of soft-marking) are admirable, it may be far more effective if it was done as a collective effort behind a representative organisation such as the ESA. We need to be better organised and effective in communicating our message of the essential role of economics instruction to all university managers.

The obstacles are likely to be substantial. Maxwell's (2003: 91) final words are worth repeating:

Moving in this direction, however, will not be an easy process. It requires change and adaptation in a difficult educational environment. ... Those [departments] that have reemerged from a period of decline have changed and evolved in unexpected and often painful ways ... economics departments in Australian universities seem destined to face a similar experience.

Unless the tide can be reversed the future may involve a significant consolidation and concentration of economics training in a far smaller number of institutions, with all of the consequences outlined in Quiggin's statement previously quoted. A worst-case scenario would even see these institutions struggling for enrolments. 


\section{Concluding remarks}

Economics enrolments have been declining for some time but this has been accompanied recently by dramatic cuts to academic positions, courses and degrees, and even departments and schools. We do appear to be in a crisis with respect to training the next generation of economists. ${ }^{14}$ Yet there is no indication that their input will not be needed as society grapples with complex and challenging public policy issues. In order to hold the fort, we need to be far more strategic and political. The Economic Society has an obvious role but has not always been effective in the past. It needs to act as an advocate for the entire economics profession. What could be done to make it more effective? Ed Wilson, from the University of Wollongong, in an email dated the 7 July 2014 to one of the authors, writes:

I understand the termination of the ERA journal rankings was brought about by judicious remarks by a few respected economic academics to a government minister's office. ${ }^{15}$... I think a group of senior economists (academic, public and private sector) should be asked to strategically approach individual VCs, Universities Australia and the like. ... collective action would be more forceful. Members of the Economic Society could initiate this. The Society could play a role by calling an urgent national one day high level symposium of related organisations including the Econometric Society, the Australian Business Economists, CEDA, etc (plus even AES and EES reps) to consider the future of teaching economics in secondary and tertiary institutions in Australia. It could be organised around the nation's future economics human capital needs.

This is an excellent suggestion. It would also be of benefit if senior economists in the public sector and academia re-engaged with the Economic Society. The Society celebrates its 90th birthday in 2014 but unless action is taken it may not reach its centenary. Even if it does, there will be little left to celebrate. Academic economists need to be far better organised and solidly behind the objective of protecting and advancing the interests of the discipline. There needs to be less in-fighting and squabbling and a greater sense of cooperation and solidarity. Economists have a legitimate purpose in being proactive to maintain

14 Is the discipline as a whole following in the footsteps of Economic History? McLean and Shanahan (2007: 301, 312) note that 'Economic historians in Australia and New Zealand have for a number of years faced declining student demand (relative or absolute) for their subject. Together with conditions of financial stringency more generally in the universities, this has led to a reduction in the number of academic posts in the field by about 50 per cent. Separate departments of economic history, which had existed in eight Australian universities, have all been abolished in this downsizing, and academic staff absorbed into departments of economics or business management. The number of full professorships in the field has declined from ten to just one ... [while] the domestic supply of PhD graduates in the field has fallen almost to zero'.

15 Bruce Chapman, then president of the Economic Society, played an important role in articulating the problems with a formal system of journal ranking. 
our disciple because there are substantial 'public' (as well as private) benefits in doing so. There is certainly the impression that other disciplines have been far more effective in advancing their interests than we have. We fail to take action at our peril. A decline in academic economics in Australia may impoverish us all.

\section{References}

Agnew, S. 2014, 'Current Trends In Economics Enrolments at Secondary and Tertiary Level', New Zealand Economic Papers, DOI:10.1080/00779954.2014 .914428, Published online: 29 May.

Alauddin, M. and Valadkhani, A. 2003, 'Causes and Implications of the Decline of the Economics Majors: A Focus on Australia', Journal of Economic and Social Policy 7(2): 68-90.

Australian Government Department of Education (various years). Selected Higher Education Statistics. Canberra, Australian Government Department of Education.

Becker, W.E. 2004, 'Goodby Old, Hello New in Teaching Economics', Australasian Journal of Economics Education 1(1): 5-17.

Bloch, H. 2012, 'An Uneven Playing Field: Rankings and Ratings for Economics in ERA 2010', Economic Papers 31(4): 418-27.

Card, D. and DellaVigna, S. 2013, 'Nine Facts about Top Journals in Economics', Journal of Economic Literature 51(1): 144-61.

Clarke, H. 1998, 'Dumbing-down in Australian universities', Quadrant 42(9): $55-9$.

Coleman, W. and Hagger, A. 2001, Exasperating calculators: the rage over economic rationalism and the campaign against Australian economists, Paddington, NSW, Macleay Press.

Coleman, W. 2004, 'Running Economics Down: Fact and Fantasy in the Presentation of Economists in the Media', Economic Papers 23(1): 58-2.

_ 2013, ‘A Young Tree Dead? The Story of Economics in Australia and New Zealand', The Australian National University, Centre for Economic Policy Research, Discussion Paper No. 688, Dec. 
Conroy, J. 2012, 'Returning Australia's Economic Debate', Business Spectator, 1 June. Available at: www.businessspectator.com.au/bs.nsf/Article/Australian economics-economic-literacybusiness-st-pd20120531STNT?OpenDocument \&emcontent_spectators.

Daly, A. and Lewis, P. 2010, 'The private rate of return to an Economics degree: an Update', Economic Papers, 29(3): 354-64.

Davidson, S. 2013, 'Excellence in Research for Australia: An Audit of the Applied Economics Rankings', Agenda 20(2): 5-20.

King, S. 2012, 'Does undergraduate economics education need to change', Core Economics, May 16.

Levitt, S.D. and Dubner, S.J. 2005, Freakonomics, New York: William Morrow/ Harper Collins.

Lewis, P and Norris, K. 1997, 'Recent changes in economics enrolments', Economic Papers 1(4): 1-13.

Marangos, J., Fourmouzi, V. and Koukouritakis, M. 2013, 'Factors that determine the decline in university student enrolments in economics in Australia: An empirical investigation', Economic Record, 89(285): 255-70.

Maxwell, P. 2003, 'The Rise and Fall (?) of Economics in Australian Universities', Economic Papers 22(1): 79-92.

McLean, I.W. and Shanahan, M.P. 2007, 'Australian Economic History: Research Challenges and Big Questions', Australian Economic History Review 47(3): 300-15.

Millmow, A. 2003, 'The teaching of economics in schools: A problem in the making?', Economic Analysis and Policy 33(1): 126-135.

_ 2006, 'Trends in economic degree enrolments within Australia 1990-2004', Australasian Journal of EconomicsEducation, 3(1): 111-24.

Millmow, A. and Tuck, J. 2011, 'Did the Global Financial Crisis Have any Impact on Economics Degree Enrolments?', Economic Papers 30: 557-67.

Murray, D. and Dollery, B. 2006, 'Institutional Breakdown? An Exploratory Taxonomy of Australian University Failure', Higher Education Policy 19(4): 479-94.

Quiggin, J. 2012, Letter to the UWS Chancellor, 9 November.

Round, D.K. and Shanahan, M.P. 2010, 'Undergraduate economics programs in Australia: Down but not out?', Journal of Economic Education 41(4): 425-35. 
Siegfreid, J.J. 2000, 'Undergraduate economics degrees trends through the 1990's', Journal of Economic Education 31(3): 296-300.

— 2011, 'Trends in Undergraduate Economics Degrees 1991-2010', Journal of Economic Education 42(3): 270-4.

- 2012, 'Two decades of trends in undergraduate economics degrees 1991 to 2011', Journal of Economic Education 43(3): 334-8.

Stokes, A. and Wright, S. 2012, 'More effectively engaging students in university economics courses', Australasian Journal of Economics Education 9(1): 1-20. 
This text taken from Agenda: A Journal of Policy Analysis and Reform Volume 21, Number 1, 2014, published November 2014 by ANU Press, The Australian National University, Canberra, Australia. 